\title{
Women in Disputes: A History of European Women in Mediation and Arbitration
}

\author{
SUSANNA HOE \& DEREK ROEBUCK, 2018
}

Oxford: Holo Books, xiv +260pp., £20. ISBN 978-0-9572153-2-0

This volume charts the involvement of women in arbitration and legal disputes, both as parties to the process and as peacemakers. The authors have set out to explore what has happened in practice over four thousand years across Europe, although the primary focus of the majority of the chapters is on the English experience. It is a jointly-authored work from wife and husband team of Susanna Hoe and Derek Roebuck. They bring to the project their respective interests and expertise. Susanna Hoe has written widely about the history of women, in particular women travellers while Derek Roebuck is an experienced lawyer with a longstanding interest in the history of dispute resolution and arbitration. The result is a richly illustrated volume on the subject. The book brings to our attention an extensive number of instances where, despite the frequent contemporary legal prohibitions, women can be observed not only as active in pursuing legal cases in support of their own interests but also as effective and respected arbitrators intervening in the disputes of others.

The wide-ranging nature of the volume means that the authors understandably have drawn extensively on the work of other authors. Hoe and Roebuck are careful to indicate the sources for their information, usually at the beginning of the discussion of individual case histories. It would, however, also have been helpful for each of the individual quotations to have its own explicit endnote reference. The lack of such details means that the reader often has to go back several pages to try to track down the full reference, which presents readers wishing to investigate cases in further depth with an additional layer of complexity. More seriously, while the authors place some secondary quotations in quotation marks, in some sections of the book they copy sentences and paragraphs directly from those works which are thus presented as their own original text.

The underlying argument running through the volume is that women were actively engaging with the arbitration process across the ages. This book would be of most value to a general reader with its wealth of nuggets of information about a wide range of women, drawn from across the social classes. Clearly women of the highest rank were the most active in this sphere, but a chapter on 'Untitled women in Medieval England' evidences energetic engagement with the arbitration process for women in lower social classes, although primarily as parties in disputes. In its appeal to a wider readership, the book fulfils the aims of Holo Books its publisher which was established two decades ago by the joint authors 'to publish scholarly books accessible to the general reader which may not appear commercial to mainstream publishers.'

The volume begins with a section on the ancient world drawing on both biblical and classical scholarship. This is followed by a series of chapters covering women in Anglo-Saxon England 
and then in medieval England and Europe. The important role of queens in particular as peaceweavers emerges clearly. Women are portrayed as having 'one thing in common: the wish to settle disputes, to resolve conflict, to make peace between and, sometimes within, counties, countries, factions, families, parties or rulers.' The next chapters continue with these same themes, exploring the roles of both titled and untitled English women. By the late medieval period, the range of available evidence is widening and allows in-depth investigation of women engaged with business in medieval London.

A brief interlude follows, as the serendipitous discovery of the records of a late medieval Maltese notary, allows Hoe and Roebuck to flesh out some brief case histories relating to women in fifteenth century Malta. The volume then returns to its focus on England with a chapter on the Elizabethan age demonstrating that women were 'routinely parties to arbitration, both public and private' and a chapter on the seventeenth century which challenges 'any assumption that women had no legal rights then, nor determination to exercise them'. The penultimate chapter is an informative chapter on the eighteenth century which provides its readers with a valuable insight into the ample range of sources which shed light on this topic. While the previous chapters had been about women who were involved in the resolution of disputes, the final chapter is an in-depth case history focusing on Anne Clifford, a seventeenth century aristocrat, who refused to submit extensive pressure from family, friends and the authorities to submit to arbitration over the disputed ownership of her father's entailed lands.

The authors' decision to include within their text extensive quotations from primary source texts as diverse as Homer's Odyssey, the Justinian Law Code, Archbishop Anselm of Canterbury, late medieval Maltese notarial records and seventeenth century Privy Council records makes us aware of the richness of the sources for the history of the engagement of women with legal processes. In addition, the use of quotations, often using quite extensive extracts, from the work of other modern scholars working in the field, will enable those whose interests are sparked by the many fascinating cases cited to follow the subject up further. This is also true of the topic-specific bibliographies which occur at the end of each of the individual chapters, although I would have welcomed their division into separate sections for primary sources and secondary works.

There are some minor errors in the text, for example (p.37) where the Anglo-Saxon king Aethelred is referred to throughout as "Ethelbert", but these are perhaps inevitable in such an informative volume. The book is rounded off by a brief glossary which is helpful for those unfamiliar with legal terminology. Susanna Hoe and Derek Roebuck have unearthed and brought to our attention a wealth of concrete examples of women active and engaged with the law, for which they are to be congratulated. 